\title{
Pengaruh Pola Asuh Orang Tua terhadap Hasil Belajar Siswa di MI At-Tablighiyah Ponjanan Timur
}

\author{
${ }^{*}$ Fitriyah Ika Astutik ${ }^{1, a}$, Zainullah Zainullah ${ }^{2, b}$, Fajriyah Fajriyah ${ }^{3, b}$ \\ 1,2,3 Institut Agama Islam Al-Khairat Pamekasan, Pamekasan, Jawa Timur, Indonesia \\ E-mail: fitriyah@ alkhairat.ac.id ${ }^{\mathrm{a}}$; guszain@ alkhairat.ac.id ${ }^{\mathrm{b}}$; fajriyah@ alkhairat.ac.id ${ }^{\mathrm{c}}$
}

\begin{abstract}
:
This study aims to determine the effect of parenting on student learning outcomes at MI AtTablighiyah Ponjanan Timur. The type of research used is quantitative research with a correlation research design. The variables involved in this study are parenting patterns and student learning outcomes. The subjects of this study were fourth grade students of MI AtTablighiyah Ponjanan Timur, Batumarmar sub-district, Pamekasan Regency. This research was conducted in March 2021. The population in this study was 32 students. This research does not require a sample because the number of students does not reach 100 people. The data collection technique in this study used a test technique in the form of a questionnaire or a questionnaire sheet. The data analysis technique used in this study uses the Product Moment Correlation formula. Based on the analysis of the questionnaire data, it was obtained that $r_{\text {count }}>r_{\text {table }}$ was $0.622>0.349$ with a significance level of 5\%, meaning that the hypothesis was accepted. So it can be concluded that there is an Influence of Parenting Patterns on Student Learning Outcomes at MI At-Tablighiyah Ponjanan Timur.
\end{abstract}

Keywords: Parenting, Learning Outcomes

\begin{abstract}
Abstrak:
Peneleitian ini bertujuan untuk mengetahui pengaruh pola asuh orang tua terhadap hasil belajar siswa di MI At-Tablighiyah Ponjanan Timur. Jenis penelitian yang digunakan adalah penelitian kuantitatif dengan desain penelitian korelasi (correlation research). Variabel yang dilibatkan dalam penelitian ini yaitu pola asuh orang tua dan hasil belajar siswa. Subyek penelitian ini adalah siswa kelas IV MI At-Tablighiyah Ponjanan Timur, kecamataan Batumarmar, Kabupaten Pamekasan. Penelitian ini di lakukan pada bulan maret 2021. Populasi dalam penelitian ini adalah sejumlah 32 siswa. Dalam penelitian ini tidak membutuhkan sampel karena jumlah siswa tidak mencapai 100 orang. Teknik pengumpulan data dalam penelitian ini menggunakan teknik tes berupa angket atau lembar kuisioner. Teknik analisis data yang digunakan dalam penelitian ini menggunakan rumus Korelasi Product Moment. Berdasarkan analisis data angket diperoleh $\boldsymbol{r}_{\text {hitung }}>\boldsymbol{r}_{\text {tabel }}$ sebesar 0,622 $>0,349$ dengan taraf signifikansi sebesar 5\% artinya hipotesis diterima. Sehingga dapat disimpulkan bahwa terdapat Pengaruh Pola Asuh Orang Tua Terhadap Hasil Belajar Siswa di MI At-Tablighiyah Ponjanan Timur.
\end{abstract}

Kata Kunci: Pola Asuh, Hasil Belajar

Cara mensitasi artikel ini:

Astutik, F. I., Zainullah, Z., \& Fajriyah, F. (2022). Pengaruh pola asuh orang tua terhadap hasil belajar siswa di MI At-Tablighiyah Ponjanan Timur. Mitra PGMI: Jurnal Kependidikan MI,

8(1), 1-7. https://doi.org/10.46963/mpgmi.v8i1.445

\section{Informasi Artikel}

* Corresponding author:

fitriyah@alkhairat.ac.id

DOI:

https://doi.org/10.46963/mpgmi.v8i1.445
Histori Artikel:

Diterima : 11/12/2021

Direvisi : $14 / 01 / 2022$

Diterbitkan : 31 / 1 / 2022 


\section{PENDAHULUAN}

Pendidikan merupakan landasan utama dalam kehidupan. Bagi manusia pendidikan merupakan suatu keharusan, karena dengan pendidikan kemampuan dan kepribadian manusia akan berkembang. Pendidikan bisa kita dapatkan dimana saja, baik di sekolah, di dalam lingkungan keluarga, dan di lingkungan masyarakat. Akan tetapi pendidikan yang paling mendasar adalah pendidikan yang didapatkan di dalam lingkungan keluarga. Karena antara lingkungan keluarga dan pendidikan adalah dua istilah yang tidak dapat dipisahkan, sebab dimana ada keluarga pasti ada pendidikan. Ketika ada orang tua yang ingin mendidik anaknya, maka pada waktu yang sama anak mendapatkan pendidikan dari orang tua. Dari sini muncul istilah "pendidikan keluarga". Artinya pendidikan yang berlangsung dalam lingkungan keluarga yang dilaksanakan oleh orang tua sebagai tugas dan tanggung jawabnya dalam mendidik anak dalam keluarga (Djamarah, 2004).

Juwariyah mengatakan "bahwa pendidikan sekolah pada dasarnya merupakan kelanjutan dari pendidikan orang tua atau keluarga. Karena itu peran guru hanya sebagai penerus dari proses pendidikan yang telah diawali dan berlangsung di dalam suatu keluarga, sehingga walaupun tidak secara sistematis anak telah memperoleh bekal pengetahuan dan kebiasaan yang ditanamkan oleh orang tua atau keluarga (Juwayriyah, 2010). Oleh karena itu, keluarga memiliki arti penting dan strategis dalam pembangunan komunitas masyarakat yang lebih luas. Kehidupan keluarga yang harmonis perlu dibangun di atas dasar sistem interaksi yang kondusif sehingga pendidikan dapat berlangsung dengan baik. Pendidikan dasar yang baik harus diberikan kepada anggota keluarga sedini mungkin dalam upaya memerankan fungsi pendidikan dalam keluarga, yaitu menumbuhkembangkan potensi laten anak, sebagai wahana untuk mentrasfer nilai-nilai dan sebagai agen transformasi kebudayaan (Djamarah, 2004). Untuk mentransfer nilai tersebut dibutuhkan komunikasi yang baik antara orang tua dengan anak. Berawal dari komunikasi yang baik inilah yang nantinya akan mempengaruhi pola asuh yang digunakan orang tua dalam mendidik anaknya.

Keluarga merupakan kesatuan yang terkecil di dalam masyarakat. Keluarga mempunyai peranan yang besar dan vital dalam mempengaruhi kehidupan anak. Lingkungan keluarga besar atau kecil mempunyai pengaruh pada pertumbuhan dan perkembangan anak. Anak-anak tumbuh dalam keluarga yang berbeda-beda, ada orang tua yang merawat dan mendukung anak mereka tetapi ada juga yang memperlakukan dengan kasar atau tidak memperhatikan psikologis anak-anaknya, ada anak yang dibesarkan dalam kehidupan dimana terjadi perceraian dan tinggal dengan orang tua angkat, ada anak yang memiliki ibu yang bekerja full-time dan hanya memiliki waktu sedikit bagi anak-anaknya, beberapa anak tumbuh di

$2 \quad$ Print - ISSN: 2443-0021

Online - ISSN: 2716-4136 
Fitriyah Ika Astutik, Zainullah \& Fajriyah Pengaruh Pola Asuh Orang Tua Terhadap Hasil Belajar Siswa di MI At-Tablighiyah Ponjanan Timur

lingkungan etnik yang beraneka ragam, sebagian keluarga miskin dan sebagian keluarga yang ekonominya rata-rata. Semua variasi yang beragam ini mempunyai pengaruh pada anak di dalam dan di luar kelas. Sikap orang tua berperan penting dalam memajukan dan menghambat pendidikan seseorang (Satiadarma \& Waruwu, 2003). Orang tua merupakan teladan yang biasa dicontoh oleh anakanaknya. Sikap dan perilaku orang tua akan ditiru oleh anak, oleh sebab itu orang tua seharusnya menerapkan pola pengasuhan anak yang baik.

Berdasarkan penelitian terdahulu, terdapat pegaruh yang positif antara pola asuh orang tua dengan prestasi belajar siswa di kabupaten Maros dengan kontribusi yang nyata (Rahma, Muhammadiyah, \& Hamidi, 2020). Kusumawati, dkk (2017) menunjukkan bahwa pola asuh orang tua memiliki pengaruh yang signifikan sebesar $51 \%$ terhadap hasil belajar siswa. Apabila pola asuh yang diberikan orang tua kepada anak itu, memiliki tingkat kedemokratisan yang tinggi, maka akan mendorong tercapainya hasil belajar yang baik pada anak (Kusumawati, Wahyudin, \& Subagiyo, 2017). Selain itu peneliti lain juga melaporkan bahwa, pengaruh pola asuh orang tua terhadap hasil belajar siswa memiliki pengaruh yang cukup baik dengan interval penilaian sebesar 66-77, karena sebaik pola asuh orang tua maka emakin baik pula tingkat kedisiplinan siswa (Sipayung, 2018).

Salah satu lembaga di tingkat sekolah dasar yang menginginkan siswanya memiliki hasil belajar yang memenuhi standar KKM adalah Madrasah Ibtidaiyah At-Tablighiyah. MI At-Tablighiyah merupakan salah satu lembaga pendidikan swasta berbasis pesantren yang berada di desa Ponjanan timur, kecamatan Batumarmar, kabupaten Pamekasan. Jumlah murid keseluruhan ada 136 siswa yang terbagi ke dalam 6 kelas. Berdasarkan observasi yang telah dilakukan peneliti, terdapat satu kelas dari keenam kelas di sekolah MI tersebut sebagian besar siswanya masih memiliki hasil belajar yang relatif rendah yaitu pada kelas IV. Hasil belajar siswa di kelas tersebut berada di bawah rata-rata nilai KKM. Dimana, rata-rata nilai KKM siswa kelas IV pada semester I tahun ajaran 2020\2021 yaitu sebesar 66,71. Selain itu peneliti juga melakukan observasi siswa diluar sekolah, yang menunjukkan bahwa siswa anak MI sudah diperbolehkan bemain gadjet. Hal ini tentunya berkaitan dengan pola asuh orang tua yang kurang baik saat di lingkungan keluarga sehingga dapat mempengaruhi hasil belajar siswa saat di sekolah. Maka dari itu, penelitian ini penting dilakukan karena pola asuh orang tua merupakan salah satu faktor penentu keberhasilan siswa khususnya dimulai dari pendidikan tingkat dasar. Berdasarkan latar belakang tersebut peneliti tertarik untuk meneliti tentang "Pengaruh Pola Asuh Orang Tua Terhadap Hasil Belajar Siswa Kelas IV di MI At-Tablighiyah Ponjanan Timur”. 
Mitra PGMI: Jurnal Kependidikan MI

Vol. 8 No. 1 Tahun 2022

\section{METODE PENELITIAN}

Jenis penelitian yang digunakan adalah penelitian kuantitatif dengan desain penelitian korelasi (correlation research). Penelitian korelasi adalah penelitian untuk mengetahui hubungan variabel yang satu dengan variabel yang lain (Sugiyono, 2020). Variabel yang dilibatkan dalam penelitian ini yaitu pola asuh orang tua dan hasil belajar siswa. Subyek penelitian ini adalah siswa kelas IV MI At-Tablighiyah Ponjanan Timur, kecamataan Batumarmar, Kabupaten Pamekasan. Penelitian ini di lakukan pada bulan maret 2021.

Populasi dalam penelitian ini adalah sejumlah 32 siswa. Populasi yaitu keseluruhan subyek penelitian, apa bila subyek kurang dari 100 orang. maka diambil semua sehingga penelitian ini merupakan penelitian populasi (Arikunto, 2014). Dalam penelitian ini tidak membutuhkan sampel karena jumlah siswa tidak mencapai 100 orang. Teknik pengumpulan data dalam penelitian ini menggunakan teknik tes berupa angket atau lembar kuisioner. Teknik Analisis data merupakan proses penyederhanaan data dalam bentuk yang mudah di baca dan di interpretasikan. Teknik analisis data yang digunakan dalam penelitian ini menggunakan rumus Korelasi Product Moment,

\section{HASIL DAN PEMBAHASAN}

Hasil dan pembahasan dalam penelitian ini menguraikan tentang pengaruh pola asuh orang tua terhadap hasil belajar siswa di MI IV MI At-Tablighiyah Ponjanan Timur pada siswa kelas IV menggunakan angket. Untuk menguji terdapat atau tidaknya pengaruh pola asuh orang tua terhadap hasil belajar siswa maka ditentukan terlebih dahulu variabel $\mathrm{X}$ dan variabel $\mathrm{Y}$. Dimana variabel $\mathrm{X}$ adalah pola asuh orang tua dan variabel Y adalah hasil belajar siswa. Kemudian dihitung nilai Mean atau rata-rata dari setiap variabel. Adapun nilai perhitungan nilai rata-rata variabel $\mathrm{X}$ dan Variabel $\mathrm{Y}$ diperoleh sebagai berikut:

Tabel.1 Rata-rata variabel X dan Variabel Y

\begin{tabular}{|c|c|c|c|c|}
\hline No. & Variabel & $\begin{array}{l}\text { Jumlah Nilai } \\
(\Sigma)\end{array}$ & Jumlah Siswa (N) & Rata-rata \\
\hline 1. & $X$ & 1220 & 32 & 38,125 \\
\hline 2. & Y & 1232 & 32 & 38,50 \\
\hline
\end{tabular}

Setelah diperoleh nilai rata-rata dari setiap variabel, maka dilakukan analisis terhadap data angket terebut dengan menggunakan rumus Korelasi Product Moment yang diperoleh hasil sebagai berikut:

$4 \quad$ Print - ISSN: 2443-0021

Online - ISSN: 2716-4136 
Fitriyah Ika Astutik, Zainullah \& Fajriyah Pengaruh Pola Asuh Orang Tua Terhadap Hasil Belajar Siswa di MI At-Tablighiyah Ponjanan Timur

Tabel 2. Persiapan Menghitung "r" Kerja

\begin{tabular}{|c|c|c|c|c|c|c|c|}
\hline $\begin{array}{c}\text { No } \\
\text { Res. }\end{array}$ & $\mathbf{X}_{\mathbf{i}}$ & $\mathbf{Y}_{\mathbf{i}}$ & $\mathbf{x}=\mathrm{X}_{\mathrm{i}}-\bar{x}$ & $\mathbf{y}=Y_{i}-\bar{y}$ & $x^{2}$ & $\mathbf{y}^{2}$ & $\mathbf{x y}$ \\
\hline 1 & 37 & 38 & -1.125 & -0.5 & 1.2656 & 0.25 & 0.5625 \\
\hline 2 & 38 & 39 & -0.125 & 0.5 & 0.0156 & 0.25 & -0.0624 \\
\hline 3 & 39 & 39 & 0.875 & 0.5 & 0.7656 & 0.25 & 0.4375 \\
\hline 4 & 36 & 38 & -2.125 & -0.5 & 4.5156 & 0.25 & 1.0625 \\
\hline 5 & 38 & 39 & -0.125 & 0.5 & 0.0156 & 0.25 & -0.0624 \\
\hline 6 & 39 & 39 & 0.875 & 0.5 & 0.7656 & 0.25 & 0.4375 \\
\hline 7 & 37 & 38 & -1.125 & -0.5 & 1.2656 & 0.25 & 0.5625 \\
\hline 8 & 38 & 38 & -0.125 & -0.5 & 0.0156 & 0.25 & 0.0624 \\
\hline 9 & 35 & 38 & -3.125 & -0.5 & 9.7656 & 0.25 & 1.5625 \\
\hline 10 & 37 & 38 & -1.125 & -0.5 & 1.2656 & 0.25 & 0.5625 \\
\hline 11 & 39 & 38 & 0.875 & -0.5 & 0.7656 & 0.25 & -0.4375 \\
\hline 12 & 39 & 39 & 0.875 & 0.5 & 0.7656 & 0.25 & 0.4375 \\
\hline 13 & 38 & 38 & -0.125 & -0.5 & 0.0156 & 0.25 & -0.0624 \\
\hline 14 & 39 & 39 & 0.875 & 0.5 & 0.7656 & 0.25 & 0.4375 \\
\hline 15 & 39 & 39 & 0.875 & 0.5 & 0.7656 & 0.25 & 0.4375 \\
\hline 16 & 38 & 38 & -0.125 & -0.5 & 0.0156 & 0.25 & 0.0624 \\
\hline 17 & 39 & 39 & 0.875 & 0.5 & 0.7656 & 0.25 & 0.4375 \\
\hline 18 & 39 & 39 & 0.875 & 0.5 & 0.7656 & 0.25 & 0.4375 \\
\hline 19 & 38 & 38 & -0.125 & -0.5 & 0.0156 & 0.25 & 0.0624 \\
\hline 20 & 39 & 39 & 0.875 & 0.5 & 0.7656 & 0.25 & 0.4375 \\
\hline 21 & 38 & 38 & -0.125 & -0.5 & 0.0156 & 0.25 & 0.0624 \\
\hline 22 & 39 & 39 & 0.875 & 0.5 & 0.7656 & 0.25 & 0.4375 \\
\hline 23 & 37 & 38 & -1.125 & -0.5 & 1.2656 & 0.25 & 0.5625 \\
\hline 24 & 39 & 39 & 0.875 & 0.5 & 0.7656 & 0.25 & 0.4375 \\
\hline 25 & 38 & 38 & -0.125 & -0.5 & 0.0156 & 0.25 & 0.0624 \\
\hline 26 & 38 & 38 & -0.125 & -0.5 & 0.0156 & 0.25 & 0.0624 \\
\hline 27 & 39 & 39 & 0.875 & 0.5 & 0.7656 & 0.25 & 0.4375 \\
\hline 28 & 39 & 39 & 0.875 & 0.5 & 0.7656 & 0.25 & 0.4375 \\
\hline 29 & 38 & 38 & -0.125 & -0.5 & 0.0156 & 0.25 & 0.0624 \\
\hline 30 & 39 & 39 & 0.875 & 0.5 & 0.7656 & 0.25 & 0.4375 \\
\hline 31 & 37 & 38 & -1.125 & -0.5 & 1.2656 & 0.25 & 0.5625 \\
\hline 32 & 38 & 39 & -0.125 & 0.5 & 0.0156 & 0.25 & -0.0624 \\
\hline Jumlah & 1220 & 1232 & $\mathbf{0}$ & $\mathbf{0}$ & 31.4992 & 8 & 9.8745 \\
\hline
\end{tabular}

Dari tabel di atas maka dapat diambil hasilnya antara lain sebagai berikut:

$\sum \mathrm{x}^{2}=31.4992$

$\sum y^{2}=8$

$\sum x y=9.8745$

Print - ISSN: 2443-0021 
Nilai di atas, kemudian dimasukkan ke dalam rumus Korelasi Product Moment dan diperoleh nilai $r_{\text {hitung }}=0,622$. Sehingga berdasarkan analisis data tersebut diperoleh $r_{\text {hitung }}>r_{\text {tabel }}$ sebesar 0,622 $>0,349$ dengan taraf signifikansi sebesar 5\% artinya hipotesis diterima. Sehingga dapat disimpulkan bahwa terdapat Pengaruh Pola Asuh Orang Tua Terhadap Hasil Belajar Siswa di MI AtTablighiyah Ponjanan Timur.

Hasil penelitian terdahuu yang sejalan dengan penelitian ini dilakukan oleh Pakiding, bahwa implikasi yang sangat penting dalam upaya menigkatkan hasil belajar adalah orang tua harus mampu menrapkan pola asuh yang baik terhadap anak-anaknya (Pakiding, 2016). Peneliti lain juga melaporkan bahwa terdapat pengaruh yang signifikan antara pola asuh orang tua terhadap hasil belajar siswa yang dibuktikan melalui hasil belajar siswa khususnya pada mata pelajaran IPS berkategori sangat baik (Widhiasih, 2017). Rahma, dkk juga membuktikan bahwa terdapat pegaruh yang posistif terhadap antara pola asuh orang tua dengan prestasi belajar siswa di kabupaten Maros dengan kontribusi yang nyata (Rahma, Muhammadiyah, \& Hamidi, 2020). Kusumawati, dkk menunjukkan bahwa pola asuh orang tua memiliki pengaruh yang signifikan sebesar $51 \%$ terhadap hasil belajar siswa. Apabila pola asuh yang diberikan orang tua kepada anak itu, memiliki tingkat kedemokratisan yang tinggi, maka akan mendorong tercapainya hasil belajar yang baik pada anak (Kusumawati, Wahyudin, \& Subagiyo, 2017). Selain itu peneliti lain juga melaporkan bahwa, pengaruh pola asuh orang tua terhadap hasil belajar siswa memiliki pengaruh yang cukup baik dengan interval penilaian sebesar 66-77, karena sebaik pola asuh orang tua maka emakin baik pula tingkat kedisiplinan siswa (Sipayung, 2018). Sehingga, berdasarkan beberapa penelitian di atas memberikan bukti bahwa pola asuh orang tua memiliki peranan yang sangat penting dalam meningkatkan hasil hasil belajar siswa, karena hal itu merupakan pendidikan yang mendasar yang diperoleh seorang siswa dari orang tua.

\section{KESIMPULAN}

Berdasarkan hasil penelitian yang telah dilakukan terdapat pengaruh yang signifikan antara pola asuh orang tua terhadap hasil belajar siswa di MI AtTablighiyah Ponjanan Timur, kecamataan Batumarmar, Kabupaten Pamekasan yang dibuktikan melalui hasil analisis data angket menggunakan rumus Korelasi Product Moment yaitu $r_{\text {hitung }}>r_{\text {tabel }}$ sebesar 0,622 $>0,349$ dengan taraf signifikansi sebesar 5\% artinya hipotesis diterima. 
Fitriyah Ika Astutik, Zainullah \& Fajriyah Pengaruh Pola Asuh Orang Tua Terhadap Hasil Belajar Siswa di MI At-Tablighiyah Ponjanan Timur

\section{REFERENSI}

Arikunto, S. (2014). Prosedur Penelitian Suatu Pendekatan Praktek. Yogyakarta: Rineka Cipta.

Djamarah, S. B. (2004). Pola komunikasi Orang tua dan Anak dalam Keluarga. Jakarta: Rieneka Cipta.

Juwayriyah. (2010). Dasar-dasar pendidikam Anak dalam Al-Qur'an. Yogyakarta: Teras.

Kusumawati, O. D., Wahyudin, A., \& Subagiyo. (2017). Pengaruh Pola Asuh, Lingkungan Masyarakat dan Kedisiplinan Belajar. Educational Management UNNES, 92.

Pakiding, S. (2016). Pengaruh Pola Asuh Orang Tua dan Lingkungan Sekolah Terhadap hasil Belajar Matematika Melalui Motivasi Belajar Siswa SMK Negeri Kecamatan Samarinda Utara. Jurnal Pendas Mahakam, 246-247.

Rahma, Muhammadiyah, M., \& Hamidi, S. (2020). Pola Asuh Orangtua Terhadap Dorongan Aktivitas Belajar dan Hasil. BJE, 1.

Satiadarma, M. P., \& Waruwu, F. E. (2003). Mendidik Kecerdasan dan Guru dalam Mendidik Anak Cerdas. Jakarta: Pustaka Populer Obor.

Sipayung, R. (2018). Pengaruh Pola Asuh Orang Tua dan Disiplin Belajar Terhadap Hasil BelajarSiswa SD Kelas V di SD Negeri Muara Bolak 4 Kec. Sosorgadong . Jurnal Ilmiah Maksitek, 14.

Sugiyono. (2020). Metode Penelitian Pendidikan Kuantitatif Kualitatif $R \& D$. Bandung: CV. Alfabeta.

Widhiasih, I. (2017). Pengaruh Pola Asuh Orang Tua Terhadap hasil Belajar IPS. Jurna Kreatif, 194-195. 